\title{
Benefit-sharing as a global bioethical principle: A participating dialogue grounded on a Protestant perspective on fellowship
}

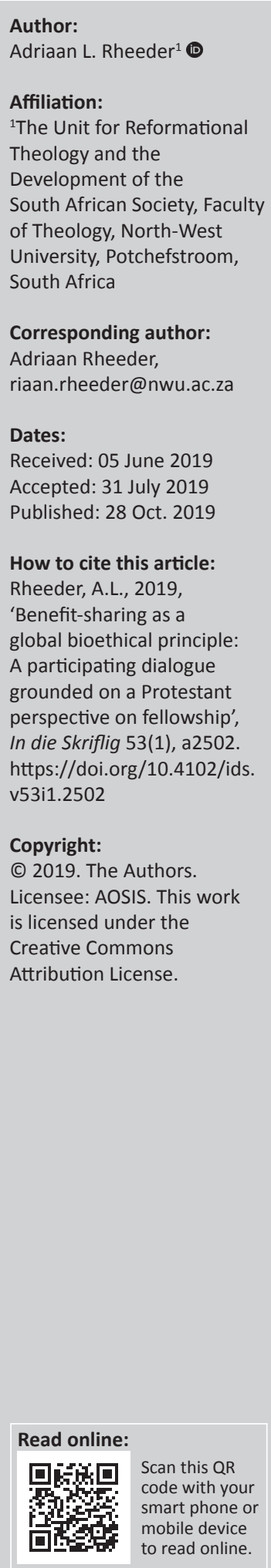

It has become evident from a practical, legal and theological perspectives that there are strong reasons that the principles underlying article 15 of the Universal Declaration of Bioethics and Human Rights (UDBHR) have to be grounded in the Bible. It is clear that the UDBHR states benefit-sharing in article 15 as a global obligation. A narrower understanding of obligation means that people participating in research has the right to share in the benefits. A broader understanding of article 15 states that it is also an obligation to share abundance in the health environment with the needy outside the context of direct research. It can be said that article 15 is based on the universal principles of equality, justice, solidarity and social responsibility. The theological argumentation indicated that it is acceptable to ground both the narrower and the broader interpretation of article 15 in the biblical concept of koinonia [fellowship]. Koinōnia can be connected with trade justice or justice-in-exchange and research, as well as the duty to share the existing abundance in the health environment with the needy. Koinonia, as an appeal to share, gives expression to equality, righteousness, solidarity and social responsibility. Article 15 of the UDBHR can be wholeheartedly supported and promoted by the Protestant faith community

Keywords: Koinonia; Fellowship; Benefit-Sharing; Global Bioethics; Human Rights; Scientific Research.

\section{Introduction}

The overarching aim of this study is to formulate a Protestant faith grounding for the global bioethical principle of benefit-sharing as described in article 15 of the Universal Declaration of Bioethics and Human Rights (UDBHR) of the United Nations Education, Science and Cultural Organization (UNESCO). Article 15 reads as follows (UNESCO 2006):

Benefits resulting from any scientific research and its applications should be shared with society as a whole and within the international community, in particular with developing countries. In giving effect to this principle, benefits may take any of the following forms:

1. special and sustainable assistance to, and acknowledgement of, the persons and groups that have taken part in the research;

2. access to quality health care;

3. provision of new diagnostic and therapeutic modalities or products stemming from research;

4. support for health services;

5. access to scientific and technological knowledge;

6. capacity-building facilities for research purposes;

7. other forms of benefit consistent with the principles set out in this Declaration.

Why is the UDBHR such an important document? For the first time in history, all states of the world (including South Africa) committed themselves unanimously to comply with bioethical principles. All other global bioethical instruments have been accepted by interest groups and cannot lay claim to universality, for example the Declaration of Helsinki (WMA), which represents the views of medical doctors only. The fact of global acceptance of the UDBHR currently makes it the most universal and authoritative bioethical instrument (IBC 2008:45; Ten Have 2016:103-104; Ten Have \& Jean 2009:17).

There are three important reasons for presenting religious grounding for human rights principles: the first is a practical reason concerned with the attitude of people towards human rights; the second is concerned with the legality of human rights; and the third is theological in nature and 
comprises the three viewpoints. These are avoiding faith grounding of human rights, connecting them to religions in the form of natural law and grounding them on the Word of God. The problem statement of this study, which will subsequently be discussed in more detail, stems from these three reasons.

The first reason, which is practical in nature, is that a considerable number of Christian individuals and faith groups are still distrustful of human rights. The global Christian non-governmental organisation, Christian Aid (working in 37 countries), which is striving to alleviate poverty by promoting human rights, reiterated their viewpoint of 2010 in 2016, saying: 'The language of human rights is increasingly contested and controversial, within the world of international development, but also within the churches and within other faith communities' (Clifford 2010:8; Durber 2016:3). Also individuals and faith traditions within Protestantism show some detachment towards the language of human rights (Webb 2018:6-7). Two recently published books, Myth of universal human rights (Stamos 2015) and Seeing the myth in human rights (Reinbold 2017), express the opinion that universal values came into existence in the same way and with the same purpose as religious myths. This negative attitude towards universal values is probably one of the reasons why the UDBHR, according to a study of Langlois (2013:154), has had no or little impact in South Africa. The most important reason for the negative attitude towards human rights, according to Christian Aid, is that human rights lack Christian faith grounding that resonates with the faith language of love, charity and compassion. Related to the conviction of Hauerwas (2012), the opinion of Christian Aid is that many believers are not easily convinced and motivated by a system that does not use the name of God openly (with the purpose of promoting universalism). 'Foundational positions are very important for many people in their lives', and therefore support of human rights will mainly arise from 'prior ethical convictions' of individuals and faith traditions. Webb (2018:13-14) supports this trend of thought. People are basically convinced and motivated by stories in their faith tradition and therefore Christian Aid has recently published a study with the title 'Putting God to Rights' (Durber 2016:18). This viewpoint is also supported by political and social philosophy. According to Rawls (1993:134), a system of universal values will only be accepted when it can be motivated from an 'own point of view'. Habermas (2012:324) lends further weight to the viewpoint that 'religious citizens have to acquire the secular legitimation of the community on the premises of their own faith' (transl. by Pirner 2016b:16-18). In the light of this statement, Pirner (2016b) writes the following:

In this way, in Habermas' German context, the two big churches the Roman-Catholic and the Protestant Church, in the course of the twentieth century have come to approve of and support liberalism, democracy and international human rights - for theological reasons and with theological arguments. (p. 18-19)
The United Nations Education, Science and Cultural Organization is very much aware of the fact that many faith traditions will not accept universal principles merely prima facie. They therefore initiated a book series, 'Religious perspectives', in which the religious grounding of the UNESCO global bioethical principles and human rights are developed precisely with the view to promote human rights in the religious community (see Tham 2014; 2018; Tham, Kwan \& Garcia 2017). The first objective of this study is therefore to promote a global bioethical value system, specifically in the Protestant faith tradition.

The second reason concerns the question of legality of human rights. It is important that a human rights document should be as representative as possible. One of the stinging points of criticism levelled at the UDBHR is that during the short period between 2003 and 2005 in which the document was developed, and despite the consensus reached, not all relevant parties were consulted and several groups feel they were not included (Ten Have 2016:101-102). During the development of the document, consultations took place with representatives from Islam, Confucianism, Buddhism, Hinduism, Roman-Catholic and Jewish traditions (Gallagher 2014:135; IBC 2004:2-4; Ten Have \& Jean 2009:31), but not with Protestant faith tradition representatives (Tham 2014:2-3). For a declaration to be truly credible and representative, it is unacceptable that a certain religious discourse and support could exclusively serve as consent to a global bioethics. The importance of the broadest religious support of these universal principles are recognised by UNESCO in the second reason for the UNESCO book series, 'Religious Perspectives', in which the Protestant religious view as well as several others are included to broaden the inclusivity of the instrument (Tham et al. 2017:xxiv). Seen from the UNESCO perspective, it is also important to engage in a dialogue with the Protestant faith tradition, as it will broaden the representative status of the UDBHR (and art. $15)$, and thus strengthen its claim to universality. The second objective of this study is thus to contribute to enhancing the representative status of article 15 .

The third reason for religious grounding of article 15 is theological in nature. In Christian thought, three points of departure regarding the relationship between human rights and Christian faith exist. The first point of departure is that all religious grounding of human rights should be avoided and that it is sufficient to accept that human rights are merely accepted to promote the best interests of people (Vorster 2017:118; Webb 2018:2). The second point of departure states that human rights should indeed be connected with religion in the form of natural law, a viewpoint supported by Christian epistemology and ethics. A special exponent of this approach is the Roman-Catholic Church (Webb 2018:4-5). According to the Foreword of the UDBHR, human rights are described as 'universal principles based on shared ethical values' (UNESCO 2006), also known as 'common morality'. Article 15 therefore originates in human reason and as a principle which has a rational and intuitive origin that can be grounded 
in natural law. A third point of departure representing Protestantism proceeds from the conviction that human rights have to be grounded in the Word. Matz (2017) writes:

For Protestants, Scripture is the ultimate authority for faith, life, and doctrine, and this is no less true in the field of social ethics ... Scripture is foundational for Protestant social ethics ... (n.p.)

Generally, Protestantism is not in denial about natural law (with Karl Barth as the exception; Vorster 2015:37-59). It is, however, convinced that natural law cannot serve as the foundation for a complete Protestant ethics (Douma 1997:70). Natural law has to be recognised and used as the revelation of God to the human being (Ps 19:1; Rm 1:18-32; 2:14-15), which enables the preliminary acceptance and use of human rights as a shared objective. Indeed, the ancient history in Genesis 1-11 (Gn 4:15; 8:22; 9:1, 5-7, 10, 12, 15-16) as well as the reign of God over all nations (Ps 22, 47, 93, 99; Mt 6:33) indicate the reality and desirability of a system of human righteousness as the universal covenant of God not only with believers, but with all humanity (König 2010:113-114; VanDrunen 2009:31; Vorster 2017:133-138). From a Protestant view, however, using natural law only is problematic, as human reason (and emotion) is marred by $\sin$ (Gn 3). An untainted nature and human reason do not exist anymore, which means evil is a continuous possibility to the end of the world (2 Th 1:5-10; 2 Tm 3:1-5; Pirner 2016a:336; VanDrunen 2009:33-36). Habermas (1999:226) is correct when he states that human rights are social constructs that should not be confused with facts or eternal truths. For this very reason, Vorster (2015:109) is of the opinion that the second commandment (Ex 20:4-6), which declares that the Word is the primary source of ethical knowledge and supposes the possibility of sinful conceptions (principles), states that the Word should serve as 'die toetssteen van alle etiese kodes en handelinge' ['acid test of all ethical codes and actions']. The fact that Genesis 9:6 indicates the reality of a universal ethical code, but still connects it to the image of God, shows that no universal code can exist without a Christian grounding. This view is confirmed by the fact that reign in the Bible is not presented as a mere neutral matter (Mk 1:14), but definitely emphasises that it is the universal reign of God ( $\mathrm{Rm}$ 14:17) and Christ (Eph 5:5). In a sinful context, the most correct manner to gain insight into ethics is through dialectic of natural law and the Word with Scripture as the primate, and in this way, forming a complete ethics (Douma 1997:56; Pirner 2016a:336). The third objective of this study is therefore ethical grounding of article 15 from the perspective of the Protestant faith tradition.

Galjaard (2009) explains article 15, saying, 'It seems more relevant than ever to pay attention to this principle, which for thousands of years forms part of the Holy writings of the major world religions.' The research question is: Is this statement of Galjaard true for the Protestant faith tradition while the central theoretical argument of the study is that this statement can indeed be grounded from the perspective of the Word. In the first place, article 15 will be interpreted methodologically from a 'UNESCO perspective' by placing the focus only on material provided by UNESCO. Secondly, the 'UNESCO perspective' will be investigated in light of the Word.

\section{Benefit-sharing}

The title of article 15 is 'Sharing of benefits'. What is meant by the global bioethical concept of benefit-sharing as declared in the UDBHR? To understand the global principle of benefit-sharing, a historical background of the concept will first be discussed. In the second place, the concept will be discussed in the context of the UDBHR.

\section{Historical background}

The international community, especially the developing world, has become convinced that the use of non-human biological material and traditional knowledge are sometimes used in an unfair way in research. This issue (as well as the ethical problem of biological diversity) inevitably compelled the United Nations in 1992 to present a conference known as the Earth Summit. During this conference, a declaration known as the Convention on Biological Diversity (CBD) was developed. Among others, an ethical principle was accepted, namely 'The fair and equitable sharing of benefits from the use of genetic resources'. This principle had been requested by the developing world since the 1970s (Ten Have 2016:213214; UNESCO 2005:10). It simply means that those who contribute to scientific research and development have to share in benefits resulting from research (Hoffmann 2016:250).

The following two examples illustrate the desirability of the CBD statement (about benefit-sharing) as bioethical principle. The first example is known as the Hoodia Succulent case. It is known that the San community used the Hoodia Succulent for hundreds of years as a replacement for food and water on long hunting expeditions because of its appetite suppressing property. From about 1963, there has been a special interest in the succulent. In 1995, the Council for Industrial and Scientific Research (CSIR) succeeded in isolating the appetite suppressing ingredient and shortly thereafter sold a license for research and product development to firms in the United States and in the United Kingdom (without any discussions with the San community). It meant that the CSIR received royalties and milestone payments from the licensees (until about 2003), while the San community received no benefits from the research and product development during the relevant period. Additionally, a large industry farming with the Hoodia Succulent (and also probably supplying the product for research) existed without the San community receiving any benefit from the commercialisation of the product (Hoffmann 2016:253; Schroeder 2014:210).

The second example is known as the Nicosan (Niprosan) case. Sickle cell disease is a life-threatening hereditary blood disease endemic to Sub-Saharan Africa. No cure exists and the only option is palliative treatment. When babies survive the disease, they face painful and disrupted lives. 
By 1992, Reverend Ogunyale of Nigeria had developed a herbal mixture by making use of a combination of local non-human biological material (plants) and traditional knowledge. He achieved extraordinary success in the symptomatic treatment of the disease. In the same year, Reverend Ogunyale and the Nigerian National Institute for Pharmaceutical Research and Development (NIPRD) signed a memorandum of understanding (MOU) to conduct further research on the herbs with a view to drug development. Between 1991 and 1998, the medication, Niprisan, was developed, and between 1998 and 2000, the remedy was patented in Nigeria, the United States, United Kingdom, India and 42 other countries. In 2002, the American company, Xechem, obtained a license to manufacture the medication and it delivered the first supply in 2006. Unfortunately, it went bankrupt in 2008 (because of corruption and mismanagement). The NIPRD continued manufacturing the medicine, but it also terminated its production in 2010 with a promise to resume production in 2012. From about 1992 to 2008, a large number of states, organisations and individuals gained great financial benefits from the herbal product of Reverend Ogunyale. He passed away in 2002, but neither he or his family nor the community to which he belonged, received any benefit from the herbal product. The same is true of the persons who participated in the clinical research: they received no financial benefit, and because the product was so expensive, they had no access to it (Schroeder 2014:211).

The purpose of benefit-sharing as accepted in the CBD is to achieve the following: people such as Reverend Ogunyale and his family and the San community, who contributed non-human biological material and traditional knowledge to research and development, should share in the benefits of the project and development in some way or other.

The principle of benefit-sharing as declared in the CBD is not limited to the use of non-human biological material and traditional knowledge in research, but it is also expanded to the use of humans and human biological material in research. This principle of benefit-sharing, relating to human participation and human biological material, is laid down for the first time in the Declaration of Helsinki (WMA) in 2000 by the concept of post-research obligations towards human participants in research (IBC 2015:6; Ten Have 2016:213-214). Paragraph 30 states this principle as follows (WMA 2000):

At the conclusion of the study, every patient entered into the study should be assured of access to the best proven prophylactic, diagnostic and therapeutic methods identified by the study.

It is clear that the human participating in research should 'be assured of access to' the positive outcomes of the research. This principle is reconfirmed in paragraph 34 of the latest Helsinki Declaration (WMA 2013). For an example illustrating this principle, refer to the provision of viruses for research (Schroeder 2014:218). In 2007, the Indonesian government decided not to share the bird flu virus with the World Health Organization (WHO). These samples were used to conduct research on the virus and then to manufacture vaccines or antiviral medication.

Countries such as Indonesia where flu epidemics frequently originate, are the first to supply samples to develop preventive and therapeutic medicines. The exchange, however, is uneven. The WHO gives the virus samples to private companies in developed countries. These companies manufacture a vaccine and make it available to populations in developed countries who are rich enough to buy it before the epidemic appears within their borders. The benefits of international cooperation thus go to the pharmaceutical companies that receive free biological and genetic material. At the same time, the individuals and countries donating the samples have to purchase the vaccine at great expense. Moreover, the persons and countries that participate in the research, do not share in the (financial and other) benefits of the research and they themselves do not receive the medicine (Ten Have 2016:211213). The purpose of benefit-sharing is the following: people participating in research have to share in the benefits of the project in some way or another.

The question arising now is what the ethical justification of this principle would be. The CBD and Helsinki decisions are grounded on the principle of justice. In philosophy and law, four forms of justice are distinguished, namely retributive justice, distributive justice (justice-as-equality), corrective justice, and finally, trade justice (justice-in-exchange). Trade justice is concerned with fairness or equality of transactions, that is, transactions where all involved receive their appropriate and fair share (Hoffmann 2016:250-252; Schroeder 2014:208). Where justice-in-exchange does not exist, exploitation takes place. It happens when someone benefits from the activities of others without the others receiving any compensation for their contribution. It is also known as expropriation without compensation.

In sum, it is clear that the CBD and the Declaration of Helsinki state an ethical and legal obligation for governments and researchers to make sure that where people or countries participate in research, benefit-sharing has to take place.

\section{The United Nations Education, Science and Cultural Organization declaration}

Against this historical background, article 15 of the Universal Declaration on Bioethics and Human Rights is now discussed. This declaration also unequivocally states benefit-sharing as an ethical and legal obligation in article 15, stating 'Benefits resulting from any scientific research and its applications should be shared ...' (UNESCO 2006). Benefit-sharing as an obligation in article 15 has narrower and broader meanings. Three narrower meanings are explained by quoting phrases from the article, while the broader meaning is investigated by endeavouring to answer a few questions.

The first of the narrower meanings is that the benefits of research have to be shared with persons and groups who are 
participating directly in research projects (IBC 2015:12; Schroeder 2014:220; UNESCO 2006; 2008:61). Article 15.1(a) describes the benefits, saying: '... benefits may take any of the following forms ... special and sustainable assistance to, and acknowledgement of, the persons and groups that have taken part in the research ...'. There has to be 'acknowledgement of' this participation by giving special and sustainable support to these participants (Galjaard 2009:240). It means, among others, according to article 15.1(c), '... provision of new diagnostic and therapeutic modalities or products stemming from research ...' (UNESCO 2006). Individuals, needing medical assistance, have to share in the diagnostic and therapeutic help of products that result from successful research (Hoffmann 2016:251). This is not only true for individuals participating in research, but also for participating groups or countries with limited resources. In this regard, UNESCO (2008) writes the following:

It is incumbent upon scientists, governments and industry to find ways for the achievements in scientific and technological research to contribute to economic and social progress to developing countries and not only to developed ones. (p. 61; see also Hoffmann 2016:248)

The second narrower meaning relates to the fact that it happens regularly that no positive results flow forth from the scientific research; in this way, the participants in the research are excluded from sharing in benefits. To solve this problem, the UDBHR suggests that benefits do not need to be directly connected with a specific research project and that other benefits may be shared with the participants in the research. This point of view is concluded from the words, 'benefits may take any of the following forms'. According to article 15.1(a), sharing benefits may be financial in nature or it may also be non-monetary in nature, for example, '... access to quality health care ...', or 'capacity-building' (art. 15.1(b)(c); UNESCO 2006). In the process, participants may be assisted with financial support, access to other existing medical or technological aid as well as employment (Hoffmann 2016:251).

An important third narrower meaning is added by the UDBHR, namely that the content of the benefit-sharing should not be determined unilaterally, but everyone participating in the research agreement must have a say in this regard (Hoffmann 2016:251; IBC 2015:12). Article 21(4), which deals with 'Transnational practices', states this principle as follows: 'When negotiating a research agreement, terms for collaboration and agreement on the benefits of research should be established with equal participation by those party to the negotiation' (UNESCO 2006; see also Schroeder 2014:221). This principle expresses equal value and common respect (Andanda et al. 2013:57; IBC 2015:12).

In the second place, the UDBHR goes further than the CBD and the Helsinki Declaration in article 15.1 by interpreting benefit-sharing in a broader way (Hoffmann 2016:247-248). In her explanation of article 15 of the UDBHR, Schroeder (2014:216) states the following: 'The UNESCO's Universal Declaration on Bioethics and Human Rights (2005) supports a more ambitious or aspirational approach to benefit-sharing, which goes beyond sharing benefits with the contributors to research' (see also UNESCO 2005:11). In order to explain the broader meaning of article 15, a number of questions are put forward.

Who can share in the benefits of research according to the broader understanding of the article? From the phrase, [b]enefits resulting from any scientific research and its applications should be shared with society as a whole and within the international community, in particular with developing countries, a broad principle is clear. It is accepted that not only people directly taking part in research are entitled to share in the benefits, but also all people have the right of access to the fruit of (any) earlier scientific research and technology in the medical environment. On the one hand, UNESCO (IBC 2015:7) acknowledges the following fact: 'Scientific research and its applications produce benefits somewhere as the result of someone's capacity, investment of resources and successful effort.' All existing medicines and medical technology is the fruit of scientific research and the extraordinary hard work of researchers and participants in research in the past. This fact, on the other hand, also implies the following:

A fair, reasonable, sustainable approach should never be intended to convey the message that, after trials, a substantial difference could be made between those who directly contributed to the success of a research project and those who were just waiting to receive the possible benefits. (IBC 2015:12)

This broader principle is based on article 27(1) of the Universal Declaration of Human Rights (1948) and article 15(b) of the International Covenant on Economic, Social and Cultural Rights (1966). These two documents declare respectively '... everyone has the right ... to share in scientific advancement and its benefits' and 'The States Parties to the present Covenant recognize the right of everyone: (b) To enjoy the benefits of scientific progress and its applications' (Schroeder 2014:216). In other words, all people have the right to share in the benefits of any research.

What does the concept 'share' in the benefits of research mean according to the broader meaning? The UNESCO defines the concept share as follows (IBC 2015:7): 'The concept of sharing, which refers to enjoying or using something jointly with others, evokes the challenge of justice.' Article 15 remarks that sharing has to take place, in particular with developing countries: 'Benefits resulting from any scientific research and its applications should be shared with ... in particular with developing countries' (Andanda et al. 2013:57). It is generally accepted, with degrees of difference, that developing countries lack resources, while developed countries have more resources available. Hoffmann (2016:248) refers to a meaningful gap between individuals, communities and countries. The principle article 15 therefore wants to state, is that the relative abundance, which exists in the health environment, should be shared (divided, distributed) responsibly (IBC 2015:14; Schroeder 2014:219-220). 
What goals do benefit-sharing want to reach, according to the broader meaning of the concept? Benefit-sharing or sharing in existing abundance wants to reach two goals. The first goal is based on the principle of equality as expressed in article 10 of the UDBHR, from which the directive stems that all inequality in the medical environment has to be diminished (UNESCO 2006). Benefits of medical science is unevenly spread over the world (UNESCO 2008:61). By distributing the relative global abundance, greater equality can be brought about (Galjaard 2009:233-234; UNESCO 2008:61). The second goal is found in article 14 of the UDBHR, which confirms 'the enjoyment of the highest attainable standard of health' is the right of every human and that this right is realised by 'promotion of health', which is the task of the State and every sector in society (UNESCO 2006). Dividing the global relative abundance can promote the health of all people in the world. Promoting health by specific sharing benefits can, according to article 15(a-g), takes place in the following ways (Schroeder 2014:220; Ten Have 2016:213-214; UNESCO 2005:11):

- Access to quality health care ('access to quality health care', art. 15.1(b)): On the one hand, this way of promoting health concerns the availability of medical care in the country, and on the other hand, the capacity of the patient to make use of it (Galjaard 2009:234-235; Hoffmann 2016:248). Quality medical care is not only promoted by medicine and technology, but also by matters not always directly or necessarily related to science and research. Examples are clean water, safe housing, sufficient food, and knowledge of hygiene and diseases (see UNESCO 2006, art. 14).

- The provision of diagnostic and therapeutic modalities ('provision of new diagnostic and therapeutic modalities or products stemming from research', art. 15.1(c)): The latest diagnostic technology, procedures and medicines, conducive to healing, are relevant here (UNESCO 2008:61).

- Providing support to health services ('support for health services', art. 15.1(d)): As an example, the international community could help financing and building clinics and hospitals where they are urgently needed (Galjaard 2009:237; Hoffmann 2016:252; IBC 2015; Ten Have 2016:213-214).

- Promotion of access to scientific and technological knowledge ('access to scientific and technological knowledge', art. 15.1(e)): Capacity can be developed through education and training (transfer of knowledge) by imparting the latest scientific and technological methods to others. Training in the latest medical development, for example, improved surgical methods and early diagnosis of abnormalities and diseases can contribute to the promotion of health (Galjaard 2009:234; Hoffmann 2016:251).

- The establishment of facilities that build capacity ('capacity-building facilities for research purposes', art. 15.1 (f)): This refers to, for example, financial support with the aim of establishing human capital (researchers and support personnel) and infrastructure (buildings, laboratories, medical schools) in the clinical and research context which, in turn, can develop and promote an own capacity (Galjaard 2009:239; Hoffmann 2016:251; IBC 2015:20). This point relates to article 24(2) of the UDBHR, which states that international cooperation is an obligation (see also Hoffmann 2016:248):

Within the framework of international cooperation, States should promote cultural and scientific cooperation and enter into bilateral and multilateral agreements enabling developing countries to build up their capacity to participate in generating and sharing scientific knowledge, the related know-how and the benefits thereof. (UNESCO 2006)

- Help with creating structures that protect people ('other forms of benefit consistent with the principles set out in this Declaration' (art. 15.1(g)): It means that global bioethical principles of the UDBHR are regarded as benefits - referring here specifically to the development of the ethics committees with the aim of protecting all people in the health environment against exploitation. Skills in countries where research ethics and infrastructure are well developed, can share this capacity with developing countries where the skills are not yet found (Galjaard 2009:238-239).

Having indicated the narrower and broader meanings of article 15 , the discussion of article 15 is concluded by indicating the different basic foundational principles that contribute to the overarching global bioethical principle of benefit-sharing.

The first basic principle is found in article 10 of the UDBHR, which describes the promotion of equality as an obligation as follows: 'The fundamental equality of all human beings in dignity and rights is to be respected so that they are treated justly and equitably' (UNESCO 2006). It has been indicated in what way the global bioethical principle of benefit-sharing promotes equality.

The second basic principle is also found in article 10 where it states that justice is an obligation. According to Ten Have (2016:211), article 15 inevitably flows from article 10 of the UDBHR. Where participation in research is concerned, trade justice necessitates that participants have to be rewarded for their contribution; thus preventing exploitation (Hoffmann 2016:250-252; Schroeder 2014:221). The broader meaning and application of benefit-sharing as a right in which all share, is regarded as a form of distributive justice (Hoffmann 2016:252; Schroeder 2014:219). It has been indicated that benefit-sharing complies with practical justice (Ten Have 2016:213-214).

The third basic principle is found in article 13 of the UDBHR and it describes solidarity and cooperation as obligations in the following way: 'Solidarity among human beings and international cooperation towards that end are to be encouraged' (UNESCO 2006). Several definitions of solidarity exist, but it briefly means the realisation of a shared humanity that inevitably leads to awareness of the health needs of other people, which results in an individual or collective will or volition to address the needs. Solidarity inevitably leads to benefit-sharing (IBC 2015:3, 7; Ten Have 2016:213-214). 
The fourth basic principle is found in article 14 of the UDBHR and it describes social responsibility for the promotion of health as an obligation. The human does not only have a responsibility for him- or herself, but also for other people. As seen in the above discussion, article 15 expresses social responsibility for health (IBC 2015:3; Ten Have 2016:211-213).

\section{Theological discussion Introductory}

It is clear from the discussion of article 15 of the UDBHR that the concept of sharing, distributing or sharing in benefits is at the core idea of the global bioethical principle.

Two recent studies, Just sharing: A Christian approach to the distribution of wealth, income and benefits (Church of Scotland 1988) and Everything in common? The theology of sharing of possessions in community in the New Testament (Gregson 2017) state the viewpoint that benefit-sharing can be related to the Bible, especially but not only, with the concept of koinonia (Gregson 2017:47; Swartley 2012:loc. 1472). According to Reumann (1994:62), 'koinōnia theology' and ethics are truly possible. In this regard, Matz (2017) writes the following in his book Introducing Protestant Social Ethics:

Two features of early Christian fellowship (koinōnia) are important for thinking about social ethics. One is their fellowship around a common mission. The other is their fellowship around shared financial burdens. (p. 62)

The term koinonia can also be understood as an alternative term for covenant (Bartos 2016:loc. 12938; Tidball 1995:379). According to Vorster (2017:142), '... the covenant produce a social ethic and the concept of human rights is founded on such a social ethic'.

The concept is generally acknowledged and used in theology and ethics - Barth (1976:116-285), Lehmann (1963:45-63, 344-352) and Volf (1998:159-214) come to mind. Reumann (2003:134), however, is of the opinion that, despite the possibility of a koinonia theology, theology has given relatively little attention to the concept and that a complete history of the use of the concept still has to be written. Reumann (2003:135-136) says the official viewpoint and discussion of the concept of koinonia in the study of the World Council of Churches, namely On the way to fuller koinonia (Best \& Gassmann 1994) can be regarded as one of the most authoritative and encompassing analyses.

The concept of koinonia in the Bible most probably has two interpretations, namely an indicative and interpretative interpretation, and they are directly linked to each other (Philip 1988:254).

\section{Fellowship with God and one another}

The first indicative meaning of the concept of koinonia can be translated as 'to share with someone in something', according to Hauck (1965:804; see also Philip 1988:254; Tidball 1995:379). The triune persons share their existence with one another in one being, which is confirmed by the reference to 'fellowship [koinōnia] of the Spirit' (Mt 28:19; 2 Cor 13:13; Phlp 2:1-2; Bartos 2016:loc. 12945; Church of Scotland 1988:64; Reumann 1994:61). John explains the fellowship, saying:

... so that you also may have fellowship with us. And our fellowship [the koinōnia] is with the [koinonia of the] Father and with his Son, Jesus Christ. (1 Jn 1:3 - NIV; see also 1 Cor 1:9 [(authors' interpretation])

That also means participation in the Holy Spirit. A deep and close relationship or fellowship exists in the Trinity (Jn 1:1-2, 14:26; König 2012:317-320). The implication of this relationship is that the human who is created in the image of God, can live in an intimate koinonia or relationship with God and his or her fellow human being. For this reason, Hauck (1965:804-805), Louw and Nida (1988:446) and Reumann (2003:134) describe koinōnia as a faith relation in the triune God (1 Cor 1:9; 9:23; 10:16-22; Phlm 6). The Holy Communion is a visible expression of koinōnia with God (1 Cor 10:14-18). Believers share their faith in the triune God.

Sin entered the world and disrupted koinonia (Gn 3:8-10), which led to contamination of the koinōnia (1 Tm 5:22; 2 Jn 11) and even caused it to become demonic in certain instances (1 Cor 10:20-21; McRay 2017:312; Tidball 1995:379). Sin implies that the human has become estranged from his fellow human beings and God, and that he or she exists in a state of estrangement and in unrighteousness towards others ( $R \mathrm{~m}$ 3:10-18). This is the reason why a peaceful and good relationship with the fellow human being and God is not possible (Bartos 2016:loc. 12949). The result of sin is isolation, estrangement and loneliness (Tidball 1995:379).

In Jesus Christ, the triune God shared again by assuming the human nature (koinonia in Heb 2:14-15) to carry the punishment for the unrighteousness of the human on the cross (Green 2011:459; Reumann 2003:134; Tidball 1995:379). A relationship with Christ now means participating (koinōnia) in the blessings of God, which includes mercy (Phlp 1:7) and cleansing by Christ (1 Jn 1: 6-7). Through faith in Christ, the new human is born, which enables a new life of koinōnia as a sanctified relationship with God and the fellow human (2 Cor 5:17-21; Reumann 1994:64; Vorster 2017:11). The relationship with God is restored in principle (Bartos 2016:loc. 12956); therefore, koinonia in the new dispensation, is a real possibility and command. All the members of the church (believers in Christ) have to proclaim this gospel of koinonia together (Phlp 1:5; Phlm 17; Gl 2:7-9; Reumann 1994:61).

To be part of the triune God in this sinful world, however, implies continuous participation in the suffering of Christ (Hauck 1965:804-805; McRay 2017:312). Koinonia is much more than only a theoretical idea, because faith in God undoubtedly leads the believer on earth to suffer, to die and to be buried just like Christ (Tidball 1995:379). Paul writes the following: 'I want to know Christ and the power of his resurrection and the fellowship of sharing [koinonia] in his sufferings, becoming like him in his death ...' (Phlp 3:10; 2 Cor 1:7; Phlp 3:10; 1 Pt 4:13; Rm 6:4; 8:17; Col 1:24; 2:24; 
Phlp 3:14; 4:14). Paul's suffering on earth is clearly described as koinonia (Phlp 1:7). Not only individuals, but also the church will suffer collectively on earth (Col 1:24; 2 Cor 1:5, 7; Church of Scotland 1988:66; Matz 2017:62). It is important for the theme of this study that the concept of koinonia, according to Reumann (1994:61), 'bluntly' emphasises the fact that up to the coming of the kingdom (1 Pt 4:13; 5:1), human existence will be continuously in a situation of $\sin$, suffering, distress and want (Gl 6:6; Rm 15:27; Phlp 4:15; 2 Cor 8-9). For this reason, the continuous appeal to share, can be expected.

It has been indicated above that believers have koinonia (faith) with (or in) the triune God. Participating in God inevitably leads to koinonia with fellow believers (1 Jn 1:3-7). In this regard, Tidball (1995:379) is of the opinion, saying: 'The vertical dimension of fellowship with God, rightly understood, cannot but lead to true fellowship with fellow believers.' The relationship of fellow believers with one another is image-ing or following the koinonia in the Trinity (Bartos 2016:loc. 12941). Believers are not created as isolated individuals or self-sufficient entities, but as humans in a relationship with God, with one another and the whole creation (see also Church of Scotland 1988:63, 66). Precisely the image of the church as a body (1 Cor 12) indicates a deep interdependence of believers in a sinful world (Bartos 2016:loc. 12941).

What is the meaning of koinōnia with fellow believers? Koinonia refers to a deep relationship (communion) or faith life that believers have and share with one another (Reumann 1994:61). To express the depth and closeness of koinonia, the New Testament uses the body and soul metaphor. Koinonia is more than friendship only and rather indicates a deep relationship with one another. Luke, the doctor, describes it as a community where all the believers 'were one in heart and mind' (Ac 4:32). They were so close to one another that two or more persons use one heart and soul. To Paul, koinonia means that believers and their circumstances are in one another's hearts (Phlp 1:7) as shown by the translation of the International Standard Version (ESV). Koinonia means that believers have compassion and sympathy with one another and that they do indeed love one another deeply (Phlp 2:1-2; Gl 2:9; Hauck 1965:807-808).

Flowing from a unity of heart and soul, is a unity of thought and feelings about ethical matters (Green 2011:458). Koinōnia points to a deep unison with one another or the state of being one in mind (Ac 2:44; Phlp 2:2). The specific matter, which believers think the same about, is that all they have on earth belongs to God and one another (Church of Scotland 1988:67). Mine is mine and yours (Ac 2:44), and according to Acts 4:32, believers told one another that they shared all their belongings (Hauck 1965). Believers were indeed one in mind about the obligation to share their abundant material possessions with one another (Rm 12:3; 15:27; 1 Tm 6:18; Heb 13:16; Hauck 1965:805-808).

\section{Fellowship with one another}

The second meaning of the concept of koinonia, namely the imperative of the word, is 'to give someone a share in something', according to Hauck (1965:808; see also Philip 1988:254). From the indicative of fellowship with God, a restored life in Christ, the reality of continuous suffering on earth as well as a deep relationship with fellow believers, the imperative to share, follows inevitably. Right through the Bible, koinōnia is realised by benefit-sharing in practice (2 Cor 8:11; Gregson 2017:180). 'Fair or just distribution is integral to fellowship, the koinonia of which the New Testament speaks', is the conclusion of an intensive study by the Church of Scotland (1988:62).

The first example of koinōnia, referred to here as trade justice or justice-in-exchange, is found in Galatians 6:6 (ESV), when Paul writes, 'One who is taught the word must share all good things with the one who teaches'. Briefly, koinonia in this verse can be understood as the ethical appeal for compensation for what is delivered (Heyns 1986:268). According to Bruce (1982:263), this verse specifically deals with fair wages or compensation as a deed of justice. The opinion of Hauck (1965:808) relates to this view when he says that this verse indicates that fair labour relations are based on the concept of reciprocity, which implies an ethic of giving and receiving or benefit-sharing (see also Reumann 1994:48). At the core of this verse is the biblical principle that a labourer is worthy of his hire (Lk 10:7; Mt 20:1-15) and that disparagement of compensation for delivered services is a deed of exploitation (Jr 22:13-14; Heyns 1986:267). A careful conclusion is that the narrower meaning of article 15, which advocates justice for participants in research (e.g. in the Hoodia Succulent and Nicosan cases), can be grounded in the concept of koinōnia.

The second example of koinonia, is the interpretation that abundance has to be shared. To share, is the unavoidable consequence of a deep faith in the resurrection of Christ who brings mercy (Belhar Confession 1986; Green 2011:458). In Acts, Luke writes the following:

And all who believed were together and had all things in common. ... Now the full number of those who believed were of one heart and soul, and no one said that any of the things that belonged to him was his own, but they had everything in common [koinonia]. And they were selling their possessions and belongings and distributing the proceeds to all, as any had need. And with great power the apostles were giving their testimony to the resurrection of the Lord Jesus ... (Ac 2:44; 4:32-33 - ESV)

In addition, sharing with other believers is also a global duty outside the boundaries of your own country (Ac 11:27-30). Matz (2017:82) sums up benefit-sharing in Acts, saying: 'The early Christians shared their meager wealth with any in their community who had need.'

A special expression of koinonia is found in 2 Corinthians 8 and 9, which describes how the churches in Macedonia, who were poor themselves (2 Cor 8:1), shared their relative 
abundance with the church in Jerusalem (Church of Scotland 1988:75; McRay 2017:312; Reumann 2003:134). The use of the concept of koinōnia in 2 Corinthians 8:4 (and 13) serves as the hermeneutical guideline in understanding the two chapters (Green 2011). After her penetrating exegesis, Gregson (2017:179) gives the following summary of these two chapters:

The example of sharing in 2 Cor 8 and 9 is one that is rooted in grace: it is God's grace that provides for those who give and motivates them $(8: 1 ; 9: 8,14)$, and it is with grace that giving takes place $(8: 4,6)$.

In the research of Gregson, the following matters, emphasised in the two chapters, are important for the theme of benefitsharing (see also Hauck 1965:808):

- Abundance is a blessing (2 Cor 8:7, 14).

- Sharing is the core of being a Christian (2 Cor 9:13), because Christ is followed in doing so (2 Cor 8:9).

- Sharing especially has vulnerable people in need and want in mind (2 Cor 8:13-14). In the first letter of John, there is a direct connection between koinonia with God (1 Jn 1:7) and help to the vulnerable human (1 Jn 3:17; see Gl 2:16; Ja 2:16).

- The aim of sharing is promoting equality. Paul says the purpose of sharing is a 'equality' between members and congregations (2 Cor 8:13-14 - ERV).

- Sharing is not only applicable in your own environment, but moves beyond your own ethnical group and beyond the boundaries of your own country. The church in Syria shared their means with the church in Israel (2 Cor 8:1; see also Ac 11:27-30).

- Sharing is love (2 Cor 9:7). Christian love means to share your abundance with people in need (1 Jn 3:17). The Bible also connects love and righteousness with each other (Hs 6:6-8; 1 Jn 3:10). Love is inward righteousness and righteousness is outgoing love. Righteousness is practised when the existing abundance is shared with those who need it (Is 58:2, 6-10; 1 Jn 3:17; Church of Scotland 1988:78-79).

From the discussion up to now, it is clear in conclusion that the church has the imperative to share abundance with fellow believers or 'own people' (1 Tm 5:8; Frame 2008:922). Benefit-sharing as a global act, is especially directed at vulnerable people as an act that promotes equality or fairness and righteousness. Benefit-sharing forms the heart of the Christian faith (also see the Belhar Confession 1986). In light of these facts, the broader understanding of article 15 of the UDBHR can provisionally be carefully grounded in Protestant ethics. The description provisionally ... carefully is used, because the counter-argument can pose that the Bible only describes benefit-sharing as a command to believers.

This brings the discussion to the third example, to show that there is a global ethical duty to share with all people. Although the concept of koinōnia in the Bible is exclusively used as an appeal to share with fellow believers, Frame (2008:922) is of the opinion that the matter of koinonia is regarded as a universal duty in the instruction of Paul to the church to do good to all people (Gl 6:10). 'The love that is expected of the believer must reach out to all people, regardless of the society they belong', Vorster (2007:154) writes. His view is based on 1 Thessalonians 5:15. The believer is called upon to love the 'stranger' (a non-believer or a Gentile) (Lv 19:18, 33-34; Church of Scotland 1988:81). In the kingdom, the believer has the task of supporting and reigning just like God has (Vorster 2017:137).

Although the gospels of Christ never use the concept of koinōnia (Reumann 1994:61), koinōnia as a global duty, can indeed be Christologically founded. It has already been indicated that there is a close relationship in the triune God. Bartos (2016:loc. 12945) is of the opinion that Christ, as the creation-mediator (Col 1:16), did not limit the miracle of relations to himself, but that he created all people in his image with the ability to enter into a relationship (see also Church of Scotland 1988:64). God shares his nature and miracle with all people. Sharing abundance with one another was therefore part of the daily existence of Jesus and his disciples. Mary shared all her possessions with Jesus and the disciples, and Christ and his disciples regularly shared what they had with the poor (Lk 8:1-3; Jn 13:29; Bartos 2016:loc. 12964; Gregson 2017:40). Additionally, the stories of feeding, show how Christ shared food and water with people (Mt 14:16), which confirms that food and water are extremely important for health. It is noteworthy that the feeding stories took place in 'heathen territory' (Bethsaida) and that Jesus shared food with all; he did not only choose certain people to help. Believers are also called upon to share with people not part of their faith (Mt 6:39; Lk 9:17; Church of Scotland 1988:65, 75; Vorster 2007:155). In light of the above discussion, Reumann (1994) thinks that koinonia is nothing else than crossing all boundaries:

A good deal has been made in the presentation above of koinōnia as a term and concept that reflects crossing the boundaries, from Palestine to the Greco-Roman world, from Semitic to Hellenistic though, from agrarian Galilee to urban centers. (p. 64)

Frame (2008:923) is further of the opinion that the duty flowing specifically from koinonia to all people is demonstrated in the context of health in the story of the Good Samaritan (Lk 10:25-37). Five points important for the theme of benefitsharing as global ethical duty can be concluded from the story.

Firstly, the Good Samaritan, who made the concept of help to the neighbour a universal duty in the health environment, did it as an outsider. The story does not indicate the cultural, ethical or national identity of the man in need, but merely describes him as a man with 'wounds'. The Samaritan does not only share with Samaritans, but with all people in need (Heyd 2018:54; Macaleer 2014:130). Secondly, according to Durante (2018), it can be concluded from this story that social responsibility for the health of all people (but especially the vulnerable person) is a duty:

A sense of responsibility to care for the health of others is evident in biblical passages, in which Jesus Christ told parables, such as 
that of the Good Samaritan, and in which He Himself acted as a healer of the sick and the embodiment of an unconditional benevolence toward the suffering of others. (p. 42)

Thirdly, Frame (2008:923) is of the opinion that the story illustrates benefit-sharing as a duty, saying: 'When we have resources that can be used to help someone, we should be generous; that's all.' This narrative truly focuses on the lack of necessary medical aids (Church of Scotland 1988:86). The Samaritan does indeed share his medical supplies (oil, wine and bandages) and hospitalises the wounded man. His actions clearly show that he shares his relative abundance (his supplies and money) with the sick man.

Fourthly, Clark (2014:64-65) thinks that the parable of the Good Samaritan (Lk 10:27-28) is a clear appeal for solidarity not only with family, friends, the local community or the nation, but also with others or the stranger. It is clear that the Good Samaritan is motivated by a realisation of a shared humanity that enabled him to see the need of another and awakened the will in him to help the other (see also Nolan 1976:60-61).

Fifthly, in this story the command for medical research can also be found. Douma (1997:49) is convinced that the stories of Christ's healings point to the duty of healing. A close correlation exists between the duty of healing and medical research in the Bible, Frame (1988:58) contends, saying: 'In Biblical terms, medical research should be regarded as part of the process of healing people. As such, it has the same biblical mandate as medical treatment itself.'

In light of these facts, the broader understanding of article 15 of the UDBHR, as the global duty towards all people, to my mind, can be grounded in Protestant social ethics. It is further clear the koinonia concept can also be connected to concepts such as equality or fairness, righteousness, solidarity, social responsibility, healing in general, healing through healthy food and water and research. The biblical teaching of koinonia produce a social ethic and the concept of human rights (and global bioethics) is founded on such a social ethic. The narrow and broad aims of article 15 of the UDBHR coincide with the main aims of the ethic of the biblical idea of koinonia (for similar argumentation see Vorster 2017:142).

\section{Conclusion}

It is clear that the UDBHR states benefit-sharing in article 15 as an obligation. A narrower understanding of obligation means that people, participating in research, has the right to share in the benefits. A broader understanding of article 15 states that it is also an obligation to share abundance in the health environment with the needy human outside the context of direct research. It can be said that article 15 is based on the universal principles of equality, justice, solidarity and social responsibility.

It has become evident from a practical, legal and theological perspective that these principles underlying article 15 of the
UDBHR have to be grounded on the Bible. The theological argumentation indicated that it is acceptable to ground both the narrower and the broader interpretation of article 15 on the biblical concept of koinōnia. Koinōnia can be connected with trade justice or justice-in-exchange and research as well as the duty to share the existing abundance in the health environment with the needy human. Koinonia, as an appeal to share, gives expression to equality, righteousness, solidarity and social responsibility. Article 15 of the UDBHR can be wholeheartedly supported and promoted by the Protestant faith community.

\section{Acknowledgements Competing interests}

I declare that I have no financial or personal relationship(s) which may have inappropriately influenced me in writing this article.

\section{Author's contributions}

I declare that I am the sole author of this research article.

\section{Ethical consideration}

This article followed all ethical standards for carrying out research without direct contact with human or animal subjects.

\section{Data availability statement}

Data sharing is not applicable to this article as no new data were created or analysed in this study.

\section{Disclaimer}

The views and opinions expressed in this article are those of the authors and do not necessarily reflect the official policy or position of any affiliated agency of the authors

\section{References}

Andanda, P., Schroeder, D., Chaturvedi, S., Mengesha, E. \& Hodges, T., 2013, 'Legal frameworks for benefit sharing: From biodiversity to human genomics', in $D$. Schroeder \& J.C. Lucas (eds.), Benefit sharing: From biodiversity to human genetics, pp. 33-64, Springer, Dordrecht.

Barth, K., 1976, 'The doctrine of creation', in G.W. Bromiley \& T.F. Torrance (eds.), Church dogmatics, vol. 3, pt. 4, Clark, Edinburgh.

Bartos, E., 2016, 'Fellowship', in M. Davie, T. Grass, S.R. Holmes, J. McDowell \& T.A Noble (eds.), New dictionary of theology: Historical and systematic, 2 nd edn., loc. 12935-12976, Inter-Varsity Press, London.

Belhar Confession, 1986, Confession of Belhar, viewed 23 July 2019, from http:// images.rca.org/docs/aboutus/BelharConfession.pdf

Best, T.F. \& Gassmann, G., 1994, On the way to fuller koinonia: Official report of the Fifth World Conference on Faith and Order, World Council of Churches, Commission on Faith Order, WCC, Geneva.

Bruce, F.F., 1982, The epistle to the Galatians, Eerdmans, Grand Rapids, MI.

Church of Scotland, 1988, Just sharing: A Christian approach to the distribution of wealth, income and benefits, Epworth, London.

Clark, M., 2014, The vision of Catholic social thought: The virtue of solidarity and the praxis of human rights, Fortress Press, Minneapolis, MN.

Clifford, P., 2010, Theology and international development: A Christian Aid report, viewed 02 May 2019, from https://www.christianaid.org.uk/sites/default/files/ 2017-08/theology-international-development-april-2010.pdf 
Douma, J., 1997, Medische ethiek, Kok, Kampen.

Durante, C., 2018, 'Philantropic healthcare: Christian conceptions of social responsibility and healthcare', in J. Tham, C. Durante \& A.G. Gómez (eds.) Religious perspectives on social responsibility in health: Towards a dialogical approach, pp. 39-49, Springer International, Cham.

Durber, S., 2016, Putting God to rights: A theological reflection on human rights, viewed 02 May 2019, https://www.christianaid.org.uk/sites/default/files/2017 08/putting-god-to-rights-report-june-2016_0.pdf

Frame, J., 2008, The doctrine of the Christian life, Presbyterian \& Reformed Publishing, Phillipsburg.

Frame, J.M., 1988, Medical ethics: Principles, persons and problems, Presbyterian \& Reformed Publishing, Phillipsburg.

Galjaard, H., 2009, 'Article 15: Sharing of benefits', in H. Ten Have \& M. Jean, (eds.) The UNESCO Universal Declaration on Bioethics and Human Rights: Background, principles and application, Ethics series, pp. 231-241, UNESCO, Paris.

Gallagher, C.M., 2014, 'A Christian consideration of human vulnerability in healthcare and research', in J. Tham, A. Garcia \& G. Miranda (eds.), Religious perspectives on human vulnerability in bioethics, pp.135-141, Springer, Dordrecht. (Advancing global bioethics 2)

Green, J.B., 2011, 'Koinonia', in J.B. Green, J.E. Lapsley, R. Miles \& A. Verhey (eds.) Dictionary of Scripture and ethics, pp. 458-459, Baker Academic, Grand Rapids, MI.

Gregson, F.J.R., 2017, Everything in common? The theology and practice of the sharing of possessions in community in the New Testament, Wipf \& Stock, Eugene, OR.

Habermas, J., 1999, 'Bestiality and humanity: A war on the border between legality and morality', Constellations: An International Journal of Critical and Democratic Theory 6, 263-272. https://doi.org/10.1111/1467-8675.00145

Habermas, J., 2012, Nachmetaphysisches Denken, 2: AufsEatze und Repliken Suhrkamp, Berlin.

Hauck, F., 1965, 'Kolvwvía', in G. Kittel (ed.), Theological dictionary of the New Testament, pp. 789-809, Eerdmans, Grand Rapids, MI.

Hauerwas, S., 2012, Rights language and the justice of God, viewed 06 May 2019, from https://www.abc.net.au/religion/rights-language-and-the-justice-of-god/10100204

Heyd, D., 2018, 'Supererogation and social responsibility: A response to Chris Durante', in J. Tham, C. Durante \& A.G. Gómez (eds.), Religious perspectives on social responsibility in health: Towards a dialogical approach, pp. 51-55, Springe International, Cham.

Heyns, J.A., 1986, Teologiese etiek: Sosiale etiek, deel 2/1, NG Kerkboekhandel, Pretoria.

Hoffmann, W.A., 2016, 'Benefit-sharing', in H. Ten Have (ed.), Encyclopedia of global bioethics, pp. 246-256, Springer International, Cham.

IBC, 2004, Eleventh Session: International Bioethics Committee of UNESCO (IBC), UNESCO Headquarters, Paris, 23-24 August 2004, viewed 18 November 2013 from http://portal.unesco.org/shs/en/files/7495/11103874181ReportClB11_en pdf/ReportClB11_en.pdf

IBC, 2008, Report of the International Bioethics Committee of UNESCO (IBC) on Consent, viewed 25 May 2016, from http://unesdoc.unesco.org/images/0017/ 001781/178124e.pdf

IBC, 2015, Report of the IBC on the principle of the sharing of benefits, viewed 04 June 2019, from https://unesdoc.unesco.org/ark:/48223/pf0000233230

König, A., 2010, Alle paaie lei na Jesus, CUM, Vereeniging.

König, A., 2012, Wie is God? CUM, Vereeniging.

Langlois, A., 2013, Negotiating bioethics: The governance of UNESCO's Bioethics Programme, Routledge, Abingdon, Oxon.

Lehmann, P.L., 1963, Ethics in a Christian context, Harper \& Row, New York.

Louw, J. \& Nida, E., 1988, Greek-English lexicon of the New Testament based on semantic domains, United Bible Societies, New York.

Macaleer, R.D., 2014, The New Testament and bioethics: Theology and basic bioethics principles, Pickwick Publications, Eugene, OR.

Matz, B., 2017, Introducing Protestant social ethics: Foundations in Scripture, history, and practice, Baker, Grand Rapids, MI.

McRay, J.R., 2017, 'Fellowship', in D.J. Treier \& W.A. Elwell (eds.), Evangelical dictionary of theology, pp. 312, Baker, Grand Rapids, MI.

Nolan, A., 1976, Jesus before Christianity: The gospel of liberation, David Philip, Cape Town.

Philip, J., 1988, 'Fellowship', in S.B. Ferguson \& D.F. Wright (eds.), New dictionary of theology, pp. 254-255, Inter-Varsity, Leicester.

Pirner, M.L., 2016a, 'Conclusion: Human rights and religion in educational contexts: Foundations and conceptional perspectives', in M.L. Pirner, J. Lähnemann \& $\mathrm{H}$. Bielefeldt (eds.), Human rights and religion in educational contexts: Interdisciplinary studies in human rights, pp. 335-345, Springer International, Cham.
Pirner, M.L., 2016b, 'Human rights, religions, and education: A theoretical framework' in M.L. Pirner, J. Lähnemann \& $\mathrm{H}$. Bielefeldt (eds.). Human rights and religion in educational contexts: Interdisciplinary studies in human rights, pp. 11-31, Springer International, Cham.

Rawls, J., 1993, Political liberalism, Columbia University Press, New York.

Reinbold, J., 2017, Seeing the myth in human rights, University of Pennsylvania Press, Philadelphia, PA.

Reumann, J., 1994, 'The Biblical witness to koinonia', in T.T.F. Best \& G. Gassmann (eds.), On the way to fuller koinonia: Official report of the Fifth World Conference on Faith and Order, pp. 38-69, Geneva. (WCC, Commission on Faith Order).

Reumann, J., 2003, 'Koinonia', in E. Fahlbusch \& G.W. Bromiley (eds.), The encyclopedia of Christianity, pp. 134-136, Eerdmans, Grand Rapids, MI.

Schroeder, D., 2014, 'Sharing of benefits', in H.A.M.J. Ten Have \& B. Gordijn (eds.), Handbook of global bioethics, pp. 203-223, Springer Science+Business Media, Dordrecht.

Stamos, D.N., 2015, Myth of universal human rights: Its origin, history, and explanation, along with a more humane way, Routledge, London.

Swartley, W.M., 2012, Health, healing and the church's mission: Biblical perspectives and moral priorities, InterVarsity Press, Downers Grove, IL.

Ten Have, H., 2016, Global bioethics: An introduction, Taylor \& Francis, London.

Ten Have, H. \& Jean, M., 2009, 'Introduction', in H. Ten Have \& M. Jean (eds.), The UNESCO Universal Declaration on Bioethics and Human Rights: Background, principles and application, pp. 17-57, Ethics series, UNESCO, Paris.

Tham, J., 2014, 'Introduction: The principle of vulnerability: Meeting ground of six religions', in J. Tham, A. Garcia \& G. Miranda (eds.), Religious perspectives on human vulnerability in bioethics, Advancing global bioethics 2, pp. 1-7, Springer, Dordrecht.

Tham, J., 2018, 'Introduction: social responsibility', in J. Tham, C. Durante \& A.G. Gómez, (eds.), Religious perspectives on social responsibility in health: Towards a dialogical approach, pp. 1-10, Springer International, Cham.

Tham, J., Kwan, K.M. \& Garcia, A., 2017, Religious perspectives on bioethics and human rights, pp. xxiii-xxviii, Springer International, Cham.

Tidball, D.J., 1995, 'Fellowship', in D.J. Atkinson, D. Field, A.F. Holmes \& O’Donovan, (eds.), New dictionary of Christian ethics \& pastoral theology, pp. 379-380, InterVarsity Press, Downers Grove, IL.

UNESCO, 2005, 'Intergovernmental meeting of experts aimed at finalizing a draft declaration on universal norms on bioethics', 1st, Paris, 2005, Second Session, Explanatory Memorandum on the elaboration of the preliminary draft declaration on universal norms on bioethics, viewed 18 November 2013, from https:// unesdoc.unesco.org/ark:/48223/pf0000139586

UNESCO, 2006, Universal declaration on bioethics and human rights, viewed 18 November 2013, from http://unesdoc.unesco.org/images/0014/001461/ 146180e.pdf

UNESCO, 2008, Bioethics core curriculum, Section 1: Syllabus, ethics education programme sector for social and human sciences, division of ethics of science and technology, viewed 18 November 2013, from http://unesdoc.unesco.org/images/ 0016/001636/163613e.pdf

VanDrunen, D., 2009, Bioethics and the Christian life: A guide to making difficult decisions, Crossway, Wheaton, IL.

Volf, M., 1998, After our likeness: The Church as the image of the Trinity, Eerdmans, Grand Rapids, MI.

Vorster, J.M., 2007, Christian attitude in the South African liberal democracy, Potchefstroom Theological Publications, Potchefstroom

Vorster, J.M., 2015, Christelike etiek in 'n sekulariserende samelewing, AOSIS, Durbanville.

Vorster, J.M., 2017, Ethical perspectives on human rights, Potchefstroom Theological Publications, Potchefstroom.

Webb, R.J., 2018, 'Religious and humanist perspectives on human rights', in H.G. Ziebertz \& C. Sterkens (eds.), Religion and civil human rights in empirical perspective, pp. 1-16, Springer International, Cham.

WMA, 2000, World Health Medical Declaration of Helsinki: Ethical Principles for Medical Research Involving Human Subjects, adopted by the 18th WMA Genera Assembly Helsinki, Finland, June 1964, latest revision by the 52nd WMA General Assembly, Edinburgh, Scotland, October 2000, viewed 13 January 2019, from https://www.wma.net/wp-content/uploads/2018/07/DoH-Oct2000.pdf

WMA, 2013, World Medical Association Declaration of Helsinki: Ethical principles for medical research involving human subject, adopted by the 18th WMA Genera Assembly, Helsinki, Finland, June 1964, and amended by the 64th WMA General Assembly Fortaleza, Brazil, October 2013, viewed 25 May 2019, from https:// www.wma.net/policies-post/wma-dolation-of-helsinki-ethical-principles-formedical-research-involving-human-subjects/a 